\title{
PENGARUH SKEMA KOMPENSASI, SELF EFFICACY DAN PENALARAN MORAL TERHADAP SLACK BUDGETING
}

\author{
Nayang Helmayunita, \\ Jurusan Akuntansi, Fakultas Ekonomi, Universitas Negeri Padang \\ nayang.helma@gmail.com
}

Ade Elsa Betavia

Jurusan Akuntansi, Fakultas Ekonomi, Universitas Negeri Padang,

elsabetavia@gmail.com

\begin{abstract}
:
This study aims to examine the effect of compensation schemes, self efficacy and moral reasoning on slack budgeting. In this study the hypothesis is proposed that in the slack inducing compensation scheme the slack budgeting will be greater than using the truth inducing compensation scheme, then managers with low self efficacy will do slack budgeting compared to those with high self efficacy. It is also proposed that the individual with low moral reasoning will do slack budgeting rather than the individual with high moral reasoning. The research design in this study was a quasi 2 × 2 laboratory experiment, with Accounting students who had sat in the $5^{\text {th }}$ semester of Padang State University as lower level managers who participated in budgeting. The statistical method used to test the hypothesis is two-way ANOVA. This study provides results that the compensation scheme can affect slack budgeting actions, self efficacy has no effect on slack budgeting actions, and the interaction between slack inducing compensation schemes with low self efficacy has no effect on slack budgeting actions. Moral reasoning affects slack budgeting actions, and at lower level managers who have low levels of moral reasoning and low levels of self efficacy, interactions with slack inducing compensation schemes affect slack budgeting actions. The results of this study can contribute in the management accounting literature related to budgetary slack and its causal factors.
\end{abstract}

Keyword: Slack Budgeting, Compensation Schemes, Self Efficacy, and Moral Reasoning. 


\section{PENDAHULUAN}

Beberapa penelitian beranggapan bahwa tindakan budgetary slack merupakan tindakan yang tidak etis dan dapat mempengaruhi kinerja dari perusahaan. Hal ini menjadikan alasan utama bahwa penelitian terkait budgetary slack ini masih penting untuk dilakukan untuk lebih menggali lagi faktor-faktor yang dapat menjadi penyebab terjadinya tindakan ini. Selain itu penelitian terkait budgetary slack dengan variabel skema kompensasi dan variabel keyakinan akan kemampuan diri (self efficacy) masih jarang digunakan. Selain itu pada penelitian ini juga akan dilihat pengaruh dari penalaran moral seseorang dalam pengambilan keputusan terkait budgetary slack.

Dalam literatur akuntansi manajemen, teori agensi dapat memberikan penjelasan mengenai kesenjangan anggaran. Menurut teori agensi, terdapat perbedaan kepentingan antara prinsipal sebagai pemilik perusahaan dengan agen sebagai pengelola perusahaan. Perbedaan kepentingan inilah yang mendorong terjadinya tindakan untuk melakukan kesenjangan anggaran (budgetary slack) oleh manajer atau agen, hal ini dapat terjadi dalam kebijakan pemberian kompensasi sesuai dengan target anggaran.

Variabel skema kompensasi pada penelitian ini menggunakan skema truth inducing dan slack inducing. Pemberian kompensasi dengan menggunakan skema truth inducing akan memotivasi para penyusun anggaran untuk dapat mengestimasi secara cermat target kinerja atau target anggaran yang harus dicapai. Para penyusun anggaran akan berusaha untuk menetapkan target sesuai dengan kemampuan yang dimiliki agar dapat mendapatkan bonus dan terhindar dari denda pada saat kinerja kurang atau melebihi dari target yang telah ditetapkan. Sedangkan skema slack inducing membuka peluang untuk terjadinya budgetary slack karena pemberian insentif akan diberikan apabila kinerja yang dicapai dapat melampaui target yang telah ditetapkan dan tidak menetapkan sistem denda. Hal ini akan membuka peluang kepada para penyusun anggaran untuk tidak memberikan estimasi terbaik mereka pada saat penyusunan anggaran agar bonus yang dijanjikan dapat diperoleh.

Selain teori agensi, teori yang lain yang dapat membantu untuk menjelaskan mengenai budgetary slack adalah theory planned behaviour (TPB). Teori ini menjelaskan bahwa seseorang akan bertindak dan mengevaluasi tindakannya berdasarkan kepada aksebilitas keyakinan mereka. Keyakinan akan kemampuan diri inilah yang disebut dengan self efficacy. Karyawan akan mengevaluasi kemampuan diri pribadi mereka sendiri pada saat penyusunan anggaran sebelum mereka menentukan target anggaran yang akan mereka tetapkan. Seseorang dengan kepribadian self efficacy yang tinggi dipercaya akan dapat mengurangi kecenderungan untuk melakukan budgetary slack karena sebelum mereka 
menentukan target kinerja mereka, mereka telah melakukan evaluasi atas kemampuan diri sendiri, dan yakin akan pencapaian kemampuan diri sendiri. Sedangkan karyawan dengan self efficacy yang rendah tidak memiliki keyakinan yang kuat akan kemampuan diri sendiri, sehingga akan berusaha untuk melakukan budgetary slack.

Pada theory planned behaviour, selain keyakinan akan kemempuan diri sendiri, keinginan seseorang untuk mengambil atau melakukan suatu tindakan juga dipengaruhi oleh tingkat moralitas individu tersebut. Menurut Kohlberg (1969), seseorang akan memiliki alasan tertentu untuk bertindak berdasarkan kepada penalaran moral masing-masing. Seseorang dengan tingkat penalaran moral yang tinggi akan mengambil tindakan yang sesuai dengan ketentuan hukum dan norma yang berlaku tidak hanya berdasarkan kepada motif keuntungan pribadi saja. Individu yang memiliki tingkat penalaran moral yang tinggi akan beranggapan bahwa budgetary slack merupakan tindakan yang tidak etis yang dapat menurunkan kinerja organisasi, sehingga individu tersebut dipercaya akan tetap menghindari tindakan budgetary slack pada kondisi apapun.

Berdasarkan penjabaran diatas, maka pada penelitian ini akan diajukan tiga pertanyaan penelitian, yaitu sebagai berikut:

1. Apakah skema kompensasi akan berpengaruh terhadap budgetary slack?

2. Apakah self efficacyakan berpengaruh terhadap budgetary slack?

3. Apakah tingkat penalaran moral dapat mempengaruhi tindakan budgetary slack?

\section{TELAAH LITERATUR}

\section{Skema Kompensasi dan Budgetary Slack}

Dalam literatur akuntansi manajemen, teori agensi dapat memberikan penjelasan mengenai kesenjangan anggaran. Menurut teori agensi, terdapat perbedaan kepentingan antara prinsipal sebagai pemilik perusahaan dengan agen sebagai pengelola perusahaan. Perbedaan kepentingan inilah yang mendorong terjadinya tindakan untuk melakukan kesenjangan anggaran (budgetary slack) oleh manajer atau agen, hal ini dapat terjadi dalam kebijakan pemberian kompensasi sesuai dengan target anggaran.

Menurut (Anggraeni, 2016) skema kompensasi terdiri dari dua yaitu truth inducing dan slack inducing, kedua skema tersebut sering digunakan dalam penelitian sebelumnya untuk melihat hubungan dan pengaruhnya terhadap kecenderungan penyusunan anggaran dalam melakukan kesenjangan anggaran. (Anggraeni, 2016) menyatakan bahwa kompensasi yang menggunakan skema slack inducing atau fixed payplus bonus merupakan skema dimana bawahan dibayar dengan gaji tetap ditambah dengan bonus jika dapat melebihi target yang ditetapkan dan tanpa denda 
(penalty). Hasil produksi yang sama atau kurang dari target yang dianggarkan maka bawahan akan menerima kompensasi berupa gaji tetap. Kompensasi menggunakan skema truth inducing atau truth inducing pay scheme adalah skema pembayaran kompensasi dihitung berdasarkan banyak gaji dan bonus yang diterima sesuai dengan target yang dianggarkan. Bawahan akan menerima kompensasi jika hasil pencapaiannya sama dengan target anggaran atau sebenarnya, apabila hasil pencapaian melebihi atau kurang dari target anggaran yang sebenarnya maka akan dikenakan denda (penalty).

(Stevens, 2002) menunjukkan bahwa pemberian insentif/kompensasi berpengaruh terhadap budgetary slack. Stevens menyatakan bahwa kompensasi melalui slack inducing berpengaruh negatif terhadap budgetary slack. Selanjutnya Menurut (Anggraeni, 2016) skema kompensasi truth inducing dan slack inducing berpengaruh terhadap budgetary slack, skema slack inducing berpengaruh terhadap peningkatan bugetary slack yang tinggi, sedangkan truth inducing berpengaruh terhadap penurunan budgetary slack yang lebih rendah. Berdasarkan atas penjelasan ini, maka hipotesis yang pertama yang diajukan adalah:

$\mathrm{H} 1$ : Ketika kompensasi yang diberikan oleh perusahaan adalah skema slack inducing, maka manajer level bawah akan cenderung untuk melakukan tindakan budgetary slack dibandingkan dengan ketika perusahaan memberikan kompensasi dengan skema truth inducing.

\section{Self Efficacy dan Slack Budgeting}

TPB secara khusus menghubungkan belief (kepercayaan) dengan attitudes, sedangkan self efficacy juga berhubungan dengan keyakinan seseorang tentang apakah ia memiliki kemampuan untuk melakukan tindakan tertentu. Self efficacy tinggi yang dimiliki oleh seseorang akan membuat orang tersebut yakin akan kemampuannya untuk menyelesaikan pekerjaannya sehingga dapat mencapai kinerja yang lebih baik, karena memiliki pikiran yang positif, dan motivasi yang kuat. Sedangkan individu yang memiliki self efficacy yang rendah cenderung kurang yakin akan kemampuan diri mereka sendiri dalam menjalan tugas karena adanya pikiran negatif dalam pikirannya seperti kegagalan serta kurang percaya diri dengan kemampuan yang dimilikinya, sehingga hal ini dapat mendorong terjadinya penyusunan anggaran yang bias dan menyebabkan terjadinya budgetary slack.

Menurut (Abdullah, 2013) pada penyusunan anggaran, self efficacy yang tinggi dapat mengurangi kecenderungan pratik budgetary slack yang dilakukan oleh penyusun anggaran, sebaliknya self efficacy rendah akan mendorong manajer untuk menciptakan budgetary slack. Manajer tingkat bawah yang memiliki self efficacytinggi cenderung mampu dalam mencapai target anggaran, sedangkan manajer tingkat bawah yang memiliki self efficacy rendah tidak yakin dalam mencapai target anggaran sehingga 
mereka melakukan budgetary slack agar lebih mudah untuk mencapai target anggaran. Berdasarkan atas penjelasan ini, maka hipotesis kedua yang diajukan adalah:

$\mathrm{H} 2$ : Manajer level bawah yang memiliki self efficacy yang rendah akan cenderung untuk melakukan budgetary slack dibandingkan dengan yang memiliki self efficacy tinggi.

Pada skema kompensasi truth inducing kompensasi bonus akan diberikan jika hasil pencapaiannya sama dengan target anggaran atau sebenarnya, apabila hasil pencapaian melebihi atau kurang dari target anggaran yang sebenarnya maka akan dikenakan denda (penalty). Hal ini dapat mendorong bawahan untuk menyusun target anggaran sesuai dengan kemampuan mereka yang sebenarnya, dan berusaha untuk memenuhi target anggaran tersebut sehingga mereka mendapatkan kompensasi tanpa mengurangi gaji pokok. Namun, skema slack inducing dihitung berdasarkan gaji tetap ditambah bonus jika manajer bawah melebihi target, tetapi jika hasil kerja di bawah atau sama dengan target anggaran, maka tidak akan dikenakan punishment.

Self efficacy yang merupakan keyakinan akan kemampuan diri akan berpengaruh terhadap budgetary slack. Bawahan yang memiliki self efficacy rendah cenderung kurang yakin akan mampu dalam menjalankan tugasnya. Self efficacy yang rendah tersebut dapat menyebabkan terjadinya budgetary slack, karena bawahan cenderung tidak memikirkan pencapaian target namun memikirkan cara untuk mendapatkan kompensasi sehingga menambah gaji pokoknya.

Pernyataan di atas dapat dikaitkan bahwa manajer tingkat bawah yang memiliki self efficacy rendah pada saat skema kompensasi slack inducing akan lebih cenderung melakukan budgetary slack karena merasa tidak mampu dengan kemampuannya sendiri dibandingkan dengan yang memiliki self efficacy yang tinggi. Berdasarkan penjelasan diatas, maka hipotesis tiga yang diajukan adalah sebagai berikut:

H3 : Ketika perusahaan menetapkan skema kompensasi slack inducing, manajer level bawah yang memiliki self efficacy yang rendah akan melakukan slack budgeting dibandingkan dengan manajer level bawah yang memiliki self efficacy yang tinggi.

\section{Penalaran Moral dan Slack Budgeting}

(Kohlberg, 1969) menunjukkan perkembangan moral pembangunan universal. Kohlberg membuat tiga urutan yang mendefinisikan serangkaian tingkat kognitif. Bagi orang pra-konvensional, resolusi dilema etika hanya didasarkan pada cost and abenefit tindakan etis. Bagi orang konvensional, resolusi didasarkan pada penghindaran bahaya terhadap orang lain yang termasuk dalam institusi sosial seseorang. Orang post-konvensional 
membingkai penilaian etis berdasarkan pada prinsip-prinsip yang terinternalisasi dan dipilih sendiri.

(Hobson, Mellon, \& Stevens, 2011) menyatakan bahwa nilai personal yang ada pada masing-masing pribadi individu akan memberikan pertimbangan dasar atas penalaran moral, hal ini akan mengakibatkan setiap individu akan memberikan respon yang berbeda terhadap suatu situasi tertentu. Pertimbangan dasar atas penalaran moral yang dimiliki oleh masing-masing individu ini akan mempengaruhi besar kecilnya slack budgeting yang dilakukan. Manajer level bawah dengan tingkat penalaran moral yang rendah akan cenderung untuk mengutamakan kepentingan pribadi, mereka akan memilih tindakan yang hanya menguntungkan kepentingan pribadi tanpa mempertimbangkan norma-norma yang berlaku dan akibat atas tindakan yang diambil tersebut. Sehingga dalam tindakan penyusunan anggaran pun akan lebih cenderung untuk melakukan slack budgeting.

Pada manajer level bawah yang memiliki tingkat penalaran moral yang tinggi akan tetap mempertimbangkan keputusan etisnya. Walaupun berada pada situasi yang memungkinkan untuk mendapatkan keuntungan pribadi. Hal ini disebabkan karena pertimbangan etis yang dimiliki. Manajer level bawah yang memiliki penalaran moral yang tinggi tetap beranggapan bahwa melakukan tindakan slack budgeting tidak sesuai dengan norma yang berlaku dan akan dapat merugikan perusahaan. Berdasarkan penjelasan diatas, maka hipotesis yang diajukan berikutnya adalah:

H4 : Pada skema kompensasi perusahaan adalah slack inducing, manajer level bawah dengan penalaran moral rendah akan cenderung melakukan slack budgeting dibandingkan dengan manajer level bawah yang memiliki penalaran moral yang tinggi

H5 : Ketika skema kompensasi perusahaan adalah slack inducing, dan manajer memiliki self efficacy yang rendah, maka manajer yang memiliki penalaran moral yang rendah akan lebih cenderung untuk melakukan slack budgeting dibandingkan dengan yang memiliki penalaran moral yang tinggi.

\section{METODE PENELITIAN}

Subjek dalam penelitian ini yaitu mahasiswa jurusan Akuntansi Fakultas Ekonomi Universitas Negeri Padang tahun masuk 2016. Mahasiswa dipilih sebagai sampel karena dianggap setelah lulus S1 dapat memasuki dunia kerja dan akan menjadi pegawai di sebuah organisasi. Mahasiswa juga cukup relevan jika dijadikan subjek dalam penelitian eksperimentasi.

Penelitian ini merupakan penelitian kuasi eksperimen. Desain kuasi eksperimen dalam penelitian ini yaitu desain faktorial $2 \times 2$. Variabel bebas pertama terdiri dari skema kompensasi yang terdiri dari truth inducing dan slack inducing, serta variabel bebas kedua yaitu self efficacy yang terdiri 
dari self efficacy tinggi dan rendah. Dan memiliki variabel pemoderasi yaitu penalaran moral yang terdiri atas penalaran moral tinggi dan penalaran moral rendah.

Penelitian ini menggunakan instrumen yang diadopsi dari Chong dan Loy (2015) untuk variabel budgetary slack, skema kompensasi, dan self efficacy. Instrumen dalam penelitian ini terdiri dari enam jenis, yaitu lembar pertama berisi ikhtisar tugas dan data diri partisipan. Bagian kedua berisi kunci kode tugas yang harus diketahui partisipan agar bisa mengerjakan kertas kerja selanjutnya. Bagian ketiga yaitu sesi belajar, hal ini berguna untuk mengetahui apakah partisipan memahami petunjuk yang telah peneliti jelaskan. Bagian keempat adalah sesi latihan atau tugas produksi 1 untuk mengetahui kemampuan yang dimiliki oleh partisipan serta menetapkan standar jumlah produksi yang diinginkan manajer atasan (peneliti). Bagian kelima dan keenam secara berturut-turut yaitu hasil sesi latihan dan estimasi reward point atau target tugas kerja selanjutnya. Bagian terakhir yaitu sesi kerja yang digunakan untuk mengukur kinerja atau hasil produksi yang sesungguhnya.

Sedangkan untuk variabel penalaran moral digunakan instrumen penelitian defining issued test (DIT) yang dikembangkan oleh Rest (2000). Instrumen ini berbentuk kasus dilema etika. Moralitas individu diukur melalui instrumen yang dikembangkan dari Rest (2000) untuk mengukur level penalaran moral individu melalui empat skenario dilema etika. Tiap skenario diikuti oleh dua belas pernyatan yang mewakili stage Kohlberg 26. Setelah memberi penilaian atas pertimbangan dalam kedua belas pernyataan tersebut, partisipan diminta mengurutkan 4 pernyataan yang paling penting bagi mereka dalam membuat keputusan. Keempat pernyataan tersebut kemudian dicocokkan dengan jawaban mereka sebelumnya atas pertimbangan dua belas pernyataan. Skor diberikan pada setiap pernyataan yang cocok dengan stage 5-6. Hasil perhitungan tersebut stage 5 dan 6 tersebut merupakan P-score (post-konvensional score) yang mewakili level penalaran moral individu. P-score dikalkulasi dengan menambahkan tiap skor dari keempat skenario dan membaginya dengan 0,40 .

Hipotesis 1, 2, dan 3 yang diajukan akan diuji dengan menggunakan analysis of variance (ANOVA). Hipotesis akan diterima apabila hasil two-way ANOVA menunjukkan nilai $p$-value lebih kecil atau sama dengan 0,05. Sedangkan untuk pengaruh penalaran moral/etika diuji dengan menggunakan Independent- Samples $T$ Test.

\section{HASIL DAN PEMBAHASAN}

\section{Cek Manipulasi dan Validasi DIT}

Eksperimen pada penelitian ini dilakukan sebanyak tiga kali, dengan total partisipan sebanyak 95 orang. Hasil analisis tahap pertama, yaitu hasil 
analisis cek manipulasi menunjukkan hasil bahwa sebanyak 92 orang partisipan telah lolos cek manipulasi, sehingga sebanyak 3 orang tidak lolos cek manipulasi. Hal ini dapat terjadi karena partisipan 2 orang tidak menyelesaikan seluruh tahapan tugas yang diberikan, dan satu orang peserta menjawab salah dalam pertanyaan cek manipulasi. Selanjutnya dilakukan analisis kedua, yaitu analisis DIT. Pada analisis DIT ini, seluruh peserta dapat menyelesaikan tugas instrumen dengan baik. Tabel 1 berikut ini menunjukkan distribusi partisipan yang melanjutkan eksperimen dan yang tidak dapat melanjutkan eksperimen karena gagal dalam menjawab pertanyaan cek manipulasi dan tidak menyelesaikan seluruh tahapan tugas yang diberikan.

\begin{tabular}{|c|c|l|c|}
\hline \multicolumn{4}{|c|}{ Tabel 1. } \\
\hline $\begin{array}{l}\text { Kelompok } \\
\text { eksperimen }\end{array}$ & $\begin{array}{l}\text { Jumlah } \\
\text { partisipan } \\
\text { Gagal Melanjutkan Eksperimen }\end{array}$ & $\begin{array}{l}\text { Jumlah } \\
\text { partisipan } \\
\text { yang gagal } \\
\text { melanjutkan } \\
\text { eksperimen }\end{array}$ & $\begin{array}{c}\text { Jumlah partisipan } \\
\text { melanjutkan } \\
\text { eksperimen }\end{array}$ \\
\hline Kelompok 1 & 29 & 2 & 27 \\
\hline Kelompok 2 & 23 & - & 23 \\
\hline Kelompok 3 & 21 & - & 21 \\
\hline Kelompok 4 & 22 & 1 & $\mathbf{9 2}$ \\
\hline Total & $\mathbf{9 5}$ & $\mathbf{3}$ & 21 \\
\hline
\end{tabular}

Berdasarkan tabel di atas menunjukkan bahwa kelompok eksperimen pertama, dari 29 orang partisipan, peserta yang jawabannya tidak dapat digunakan dalam eksperimen karena tidak menyelesaikan seluruh tahapan tugas yang diberikan adalah sebanyak 2 orang, sehingga hanya sebanyak 27 orang yang jawabannya dapat digunakan dalam eksperimen. Pada kelompok kedua, dari 23 orang partisipan, semua partisipan dapat menjawab dengan benar pertanyaan cek manipulasi, dan juga dapat menyelesaikan seluruh tahapan tugas yang diberikan. Pada kelompok ketiga, dari 21 orang partisipan, semua partisipan juga dapat menjawab dengan benar pertanyaan cek manipulasi, dan juga dapat menyelesaikan seluruh tahapan tugas yang diberikan. Pada kelompok keempat, dari 22 orang partisipan, peserta yang jawabannya tidak dapat digunakan dalam eksperimen karena gagal menjawab cek manipulasi adalah 1 orang, sehingga hanya sebanyak 21 orang partisipan yang jawabannya dapat digunakan dalam eksperimen. 


\section{Statistik Deskriptif}

Tabel 2 di bawah ini menggambarkan karakteristik demografis partisipan berdasarkan kelompok yang datanya dapat dipakai dalam eksperimen. Dari tabel tersebut dapat diketahui bahwa sebagian besar partisipan adalah wanita yaitu sebanyak 72 orang (78.26\%). Pada kelompok 1 sampai dengan kelompok 4 lebih didominasi oleh partisipan wanita. Dari tabel tersebut juga dapat diketahui bahwa seluruh partisipan berada pada semester $5(100 \%)$.

\begin{tabular}{|c|c|c|c|}
\hline \multicolumn{4}{|c|}{ Tabel 2 Karakteristik Demografis } \\
\hline $\begin{array}{l}\text { Kelompok } \\
\text { eksperimen }\end{array}$ & $\begin{array}{c}\text { Jumlah } \\
\text { partisipan } \\
\text { yang } \\
\text { melanjutkan } \\
\text { eksperimen }\end{array}$ & Jenis Kelamin & Semester \\
\hline Kelompok 1 & 27 orang & $\begin{array}{l}\text { Wanita: } 23 \\
\text { orang } \\
\text { (85,19\%) } \\
\text { Pria: } 4 \text { orang } \\
(14,81 \%)\end{array}$ & $\begin{array}{c}\text { Semester 5: } 27 \text { orang } \\
(100 \%) \text {, } \\
\text { Semester 7: } 0 \text { orang } \\
(0 \%)\end{array}$ \\
\hline Kelompok 2 & 23 orang & $\begin{array}{c}\text { Wanita: } 16 \\
\text { orang } \\
(69,57 \%) \\
\text { Pria: } 7 \text { orang } \\
(30,43 \%)\end{array}$ & $\begin{array}{c}\text { Semester } 5: 23 \text { orang } \\
(100 \%), \\
\text { Semester } 7: 0 \text { orang } \\
(0 \%)\end{array}$ \\
\hline Kelompok 3 & 21 orang & $\begin{array}{c}\text { Wanita: } 14 \\
\text { orang }(66,67 \%) \\
\text { Pria: } 7 \text { orang } \\
(33,33 \%)\end{array}$ & $\begin{array}{c}\text { Semester 5: } 21 \text { orang } \\
(100 \%), S \\
\text { Semester } 7: 0 \text { orang } \\
(0 \%)\end{array}$ \\
\hline Kelompok 4 & 21 orang & $\begin{array}{c}\text { Wanita: } 19 \\
\text { orang }(90,48 \%) \\
\text { Pria: } 2 \text { orang } \\
(9,52 \%)\end{array}$ & $\begin{array}{c}\text { Semester 5: } 21 \text { orang } \\
(100 \%), \\
\text { Semester 7: } 0 \text { orang } \\
(0 \%)\end{array}$ \\
\hline
\end{tabular}

\section{Pengujian Hipotesis}

Variabel dependen yang diuji dalam penelitian ini adalah slack budgetig. Sedangkan variabel independen dalam penelitian ini ada dua, yaitu skema kompensasi dan self efficacy. Skema kompensasi dibagi menjadi dua situasi, yaitu truth inducing, dan slack inducing. Skema kompensasi truth inducing digambarkan bahwa kompensasi dihitung berdasarkan gaji tetap yang 
diterima partisipan sebesar Rp 20.000, jika hasil kerja sesuai dengan target yang ditetapkan, maka partisipan akan mendapatkan bonus sebesar Rp.5.000, namun apabila hasil kerja melebihi target anggaran produksi ataupun kurang dari target, maka gaji tetap akan dikurangi sebesar Rp 5.000. Skema kompensasi slack inducing digambarkan dimana partisipan akan diberikan gaji tetap sebesar Rp.20.000, ditambah dengan bonus sebesar Rp.5.000 untuk hasil kerja yang melewati target anggaran, jika hasil kerja kurang atau sama dengan target anggaran, maka tidak dikenakan punishment.

Variabel self efficacy menggunakan pengukuran yang digunakan oleh Ardiyani (2017), dimana dalam penelitian Ardiyani partisipan dibagi menjadi dua kelompok self efficacy. Kelompok pertama, partisipan yang dapat mencapai target anggaran dikelompokkan menjadi self efficacy tinggi, dan kelompok dua partisipan yang tidak dapat mencapai target anggaran dikelompokkan menjadi self efficacy rendah.

Uji normalitas dilakukan untuk mengetahui apakah data dalam penelitian ini terdistribusi dengan normal. Hasil pengujian normalitas dengan Kolmogorov-Smirnov Test menunjukkan nilai Asymp. Sig adalah 0,065 , nilai ini berada diatas nilai a 0,05 (tabel 3). sehingga dengan hasil tersebut dapat dikatakan bahwa data terdistribusi dengan normal sehingga memenuhi salah satu asumsi analysis of variance (ANOVA).

Tabel 3

Uji Normalitas

One-Sample Kolmogorov-Smirnov Test

\begin{tabular}{|cl|r|}
\hline & & BS \\
\hline $\mathrm{N}$ & Mean & 92 \\
Normal & & - \\
Parameters $^{\mathrm{a}}$ & Std. Deviation & .0066 \\
& & 1.01 \\
& & 435 \\
Most Extreme & Absolute & .137 \\
Differences & Positive & .137 \\
& Negative & -.121 \\
Kolmogorov-Smirnov Z & & 1.31 \\
& & 0 \\
Asymp. Sig. (2-tailed) & & .065 \\
\hline
\end{tabular}




\section{Tabel 4}

\section{Levene's Test of Equality of Error Variances ${ }^{a}$}

Dependent Variable:BS

\begin{tabular}{|r|r|r|r|}
\hline$F$ & df1 & df2 & Sig. \\
\hline 2.50 & 3 & 88 & .061 \\
\hline
\end{tabular}

Tests the null hypothesis that the error variance of the

dependent variable is equal across groups.

a. Design: Intercept $+\mathrm{SK}+\mathrm{SE}+\mathrm{SK} * \mathrm{SE}$

a. Test distribution is Normal.

Test of homogeneity of variance juga dilakukan untuk mengetahui apakah keempat grup (grup 1,2,3, dan 4) mempunyai varian yang sama. Hasil uji statistik menunjukkan nilai levene statistic sebesar 0,061 nilai berada diatas 0,05 (tabel 4). Hal ini menunjukkan bahwa setiap kelompok subjek memenuhi varian yang sama sehingga telah memenuhi asumsi ANOVA (Hair et al, 2006).

Berdasarkan hasil yang terdapat pada tabel 5, dapat disimpulkan bahwa terdapat perbedaan rata-rata nilai slack budgeting, dengan nilai $\mathrm{F}$ adalah 1.384 dengan nilai signifikansi 0.253 . Pada tabel 5 ini juga digunakan untuk pengujian hipotesis 1,2 , dan 3 .

Hipotesis penelitian ( $\mathrm{H} 1)$ memprediksi bahwa ketika kompensasi yang diberikan adalah skema slack inducing, maka manajer level bawah akan cenderung untuk melakukan tindakan budgetary slack dibandingkan dengan ketika perusahaan memberikan kompensasi dengan skema truth inducing. Hasil pengujian data pada tabel 5 menunjukkan bahwa skema kompensasi dapat mempengaruhi tindakan slack budgeting dengan nilai $\mathrm{F}=4.125$ dengan tingkat signifikansi 0,045 (skema truth inducing pada kasus 1 dan 3, dengan slack inducing kasus 2 dan 4). Sehingga dapat disimpulkan bahwa skema kompensasi memiliki pengaruh yang signifikan terhadap tindakan slack budgeting. Hal ini menunjukkan bahwa hipotesis $\mathrm{H} 1$ diterima. 
Tabel 5

Tests of Between-Subjects Effects

Dependent

Variable:BS

\begin{tabular}{|l|r|r|r|r|r|}
\hline Source & \multicolumn{1}{c|}{$\begin{array}{c}\text { Type III Sum } \\
\text { of Squares }\end{array}$} & \multicolumn{1}{c|}{ df } & \multicolumn{1}{c|}{$\begin{array}{c}\text { Mean } \\
\text { Square }\end{array}$} & \multicolumn{1}{c|}{$\mathrm{F}$} & \multicolumn{1}{c|}{ Sig. } \\
\hline Corrected Model & $4.218^{\mathrm{a}}$ & 3 & 1.406 & 1.384 & .253 \\
Intercept & .000 & 1 & .000 & .000 & .989 \\
SK & 4.192 & 1 & 4.192 & 4.125 & .045 \\
SE & .016 & 1 & .016 & .016 & .900 \\
SK * SE & .000 & 1 & .000 & .000 & .986 \\
Error & 89.414 & 88 & 1.016 & & \\
Total & 93.635 & 92 & & & \\
Corrected Total & 93.631 & 91 & & & \\
\hline
\end{tabular}

a. R Squared $=, 045$ (Adjusted $\mathrm{R}$

Squared $=, 012$ )

Hipotesis penelitian ( $\mathrm{H} 2)$ memprediksi bahwa manajer level bawah yang memiliki self efficacy yang rendah akan cenderung untuk melakukan slack budgeting dibandingkan dengan yang memiliki self efficacy yang tinggi. Hasil pengujian pada tabel 5 menunjukkan bahwa tingkat self efficacy tidak dapat mempengaruhi kecenderungan untuk melakukan tindakan slack budgeting dengan nilai $\mathrm{F}=0,016$ dengan tingkat signifikansi 0,900 (self efficacy tinggi kasus 1 dan 2 dengan self efficacy rendah kasus 3 dan 4) ). Sehingga dapat disimpulkan bahwa self efficacy tidak mempengaruhi manajer level bawah untuk melakukan tindakan slack budgeting. Hal ini menunjukkan bahwa hipotesis dua $(\mathrm{H} 2)$ ditolak.

Hipotesis (H3) menyatakan bahwa ketika perusahaan menetapkan skema kompensasi slack inducing, manajer level bawah yang memiliki self efficacy yang rendah akan melakukan slack budgeting dibandingkan dengan manajer level bawah yang memiliki self efficacy yang tinggi. Hasil pengujian pada tabel 5 menunjukkan bahwa nilai $\mathrm{F}$ adalah 0,00 dengan tingkat signifikansi 0,989. Hal ini menunjukkan bahwa hipotesis (H3) tidak dapat diterima.

Pada tabel 6 ditunjukkan statistik deskriptif P-score partisipan yang digunakan menentukan tingkat pertimbangan etika partisipan (moral reasoning). Dari tabel 6 dapat dilihat bahwa nilai maksimum P-score diperoleh sebesar 55 sedangkan nilai minimum adalah 7.50. Nilai cut-off 
untuk menentukan tingkat penalaran moral tinggi atau rendah digunakan nilai median (Ponemon, 1992). Nilai median P-score diperoleh 25,00. Partisipan yang memiliki $P$-score di atas 25,00 dikelompokkan sebagai partisipan yang memiliki tingkat penalaran moral tinggi, sedangkan partisipan yang memiliki $P$-score di bawah 25,00 dikelompokkan sebagai partisipan yang memiliki tingkat penalaran moral rendah.

\section{Tabel 6}

Statistics

\begin{tabular}{|l|r|}
\hline \multicolumn{1}{|c|}{ Valid $\quad$ Missing } & 92 \\
Mean & 0 \\
Std. Error of Mean & 25.7065 \\
Median & 1.13205 \\
Mode & 25.0000 \\
Std. Deviation & 22.50 \\
& 1.08583 \\
Variance & 1 \\
Range & 117.902 \\
Minimum & 47.50 \\
Maximum & 7.50 \\
Sum & 55.00 \\
\end{tabular}

Pada penelitian ini hipotesis keempat $(\mathrm{H} 4)$ yang diajukan adalah pada saat perusahaan memiliki skema kompensasi slack inducing, manajer level bawah dengan penalaran moral rendah akan cenderung melakukan slack budgeting dibandingkan dengan manajer level bawah yang memiliki penalaran moral yang tinggi. Untuk menguji hipotesis ini digunakan Independent-Samples T Test untuk membandingkan mean tindakan slack budgeting antara manajer level bawah yang memiliki tingkat penalaran moral yang tinggi dengan individu yang memiliki tingkat penalaran moral rendah (K3 dan K4). Dari tabel 7 di bawah ini diketahui bahwa mean nilai slack budgeting dengan tingkat penalaran moral tinggi adalah $-0,3240$, sedangkan manajer level bawah dengan level moral rendah adalah 0,7101. Untuk melihat apakah perbedaan ini signifikan atau tidak dapat dilihat dari nilai sig yang memberikan hasil sebesar 0,043. Hal ini memberikan arti bahwa ternyata terdapat perbedaan yang signifikan antara manajer level bawah yang memiliki level moral yang tinggi dengan manajer level bawah dengan level moral yang rendah terhadap slack budgeting. Sehingga Hipotesis (H4) diterima. 
Tabel 7

Group Statistics

\begin{tabular}{|l|c|l|l|c|c|c|l|}
\hline & DIT & & Mean & $\begin{array}{c}\text { Std. } \\
\text { Deviation }\end{array}$ & $\begin{array}{c}\text { Std. } \\
\text { Error } \\
\text { Mean }\end{array}$ & $\mathrm{F}$ & Sig \\
\hline Slack & tinggi & 1 & -.3240 & 1.63960 & .35779 & 4.351 & 043 \\
Budgeting rendah & 3 & .7101 & .54060 & .11272 & & \\
\hline
\end{tabular}

Hipotesis lima (H5) yang diajukan adalah ketika skema kompensasi perusahaan adalah slack inducing, dan manajer memiliki self efficacy yang rendah, maka manajer yang memiliki penalaran moral yang rendah akan lebih cenderung untuk melakukan slack budgeting dibandingkan dengan yang memiliki penalaran moral yang tinggi. Untuk menguji hipotesis ini digunakan Independent-Samples $T$ Test untuk membandingkan mean tindakan slack budgeting antara manajer level bawah dengan level moral rendah dengan manajer level bawah dengan level moral tinggi. Dari tabel 8 di bawah ini dapat diketahui bahwa mean nilai slack budgeting pada skema kompensasi slack inducing pada saat manajer level bawah memiliki self efficacy rendah namun memiliki tingkat penalaran moral yang tinggi adalah sebesar -0,6336, sedangkan untuk manajer level bawah yang memiliki tingkat penalaran moral rendah memiliki nilai mean sebesar 0,7203 . Untuk nilai signifikansinya adalah sebesar 0,015. Hal ini memberikan arti bahwa ketika skema kompensasi perusahaan adalah slack inducing, dan manajer memiliki self efficacy yang rendah, maka manajer yang memiliki penalaran moral yang rendah akan lebih cenderung untuk melakukan slack budgeting dibandingkan dengan yang memiliki penalaran moral yang tinggi. Sehingga hipotesis lima (H5) dapat diterima. 


\section{Tabel 8}

Group Statistics

\begin{tabular}{|ll|l|l|l|l|l|l|}
\hline & PIT & $\mathrm{N}$ & Mean & $\begin{array}{l}\text { Std. } \\
\text { Deviation }\end{array}$ & $\begin{array}{l}\text { Std. } \\
\text { Error } \\
\text { Mean }\end{array}$ & $\mathrm{F}$ & Sig \\
\hline $\begin{array}{l}\text { Slack } \\
\text { Budgeting }\end{array}$ & tinggi & 8 & -.6336 & 1.44881 & .51223 & 7.205 & 015 \\
& rendah & 13 & .7203 & .52964 & .14690 & & \\
\hline
\end{tabular}

\section{Pembahasan}

Hipotesis pertama menyatakan bahwa ketika kompensasi yang diberikan oleh perusahaan adalah skema slack inducing, maka manajer level bawah akan cenderung untuk melakukan tindakan budgetary slack dibandingkan dengan ketika perusahaan memberikan kompensasi dengan skema truth inducing. Berdasarkan hasil olahan data menunjukkan nilai signifikansi sebesar 0.045 , hal ini menunjukkan bahwa hipotesis pertama dapat diterima. Hasil ini sesuai dengan hasil penelitian Anggraeni (2016) yang menyatakan bahwa kompensasi yang menggunakan skema slack inducing atau fixed payplus bonus merupakan skema dimana bawahan dibayar dengan gaji tetap ditambah dengan bonus jika dapat melebihi target yang ditetapkan dan tanpa denda (penalty). Hasil produksi yang sama atau kurang dari target yang dianggarkan maka bawahan akan menerima kompensasi berupa gaji tetap.

Waller (1988) menyatakan anggaran digunakan untuk mendorong atau memotivasi bawahan dalam bekerja untuk memaksimalkan kinerjanya. Motivasi bawahan dapat dilakukan dengan cara memberikan penghargaan, hadiah, pujian, atau kompensasi serta bonus. Menurut Scott (2015:22) peranan perencanaan kompensasi eksekutif dalam memotivasi dan mengendalikan operasi manajemen perusahaan. Bawahan mempunyai perbedaan persepsi dan kebutuhan nilai kompensasi, sehingga atasan mempertimbangkan metode atau skema kompensasi yang digunakan.

Hipotesis kedua menyatakan bahwa manajer level bawah yang memiliki self efficacy yang rendah akan cenderung untuk melakukan budgetary slack dibandingkan dengan yang memiliki self efficacy tinggi. Berdasarkan hasil analisis data, didapatkan nilai signifikansi sebesar 0.900 , hal ini memberikan arti bahwa hipotesis kedua ditolak. Hasil penelitian ini tidak sejalan dengan penelitian yang dilakukan oleh Abdullah (2013) yang menyatakan bahwa pada penyusunan anggaran, self efficacy yang tinggi dapat mengurangi kecenderungan praktik budgetary slack yang dilakukan oleh penyusun anggaran, sebaliknya self efficacy rendah akan mendorong manajer untuk menciptakan budgetary slack. Berdasarkan uji statistik variabel self efficacy 
tidak mempengaruhi manajer level bawah untuk melakukan tidakan slack budgeting. Hal ini memperlihatkan bahwa antara manajer level bawah yang memiliki tingkat kepercayaan diri yang tinggi dengan manajer level bawah yang memiliki tingkat kepercayaan diri yang rendah tidak berpengaruh terhadap tindakan slack budgeting.

Hipotesis ketiga menyatakan bahwa ketika perusahaan menetapkan skema kompensasi slack inducing, manajer level bawah yang memiliki self efficacy yang rendah akan melakukan slack budgeting dibandingkan dengan manajer level bawah yang memiliki self efficacy yang tinggi. Berdasarkan uji statistik diperoleh nilai signifikansi sebesar 0.986, hal ini berarti bahwa hipotesis ketiga ditolak. Hasil penelitian ini memberikan arti bahwa pada saat terdapat situasi skema kompensasi slack inducing, tidak terdapat perbedaan antara manajer level bawah yang memiliki tingkat kepercayaan diri yang tinggi dengan manajer level bawah yang memiliki tingkat kepercayaan diri yang rendah dalam melakukan tindakan slack budgeting.

Hipotesis keempat menyatakan bahwa ketika skema kompensasi perusahaan adalah slack inducing, manajer level bawah dengan penalaran moral rendah akan cenderung melakukan slack budgeting dibandingkan dengan manajer level bawah yang memiliki penalaran moral yang tinggi. Berdasarkan hasil pengolahan data, didapatkan nilai signifikansi sebesar 0.043. hal ini menunjukkan bukti bahwa terdapat perbedaan yang signifikan antara manajer level bawah yang memiliki penalaran moral yang tinggi dengan manajer level bawah yang memiliki penalaran moral yang rendah terhadap tindakan slack budgeting. Hasil penelitian ini sesuai dengan penelitian Hobson (2011) yang menyatakan bahwa nilai personal yang ada pada masing-masing pribadi individu akan memberikan pertimbangan dasar atas penalaran moral, hal ini akan mengakibatkan setiap individu akan memberikan respon yang berbeda terhadap suatu situasi tertentu. Pertimbangan dasar atas penalaran moral yang dimiliki oleh masing-masing individu ini akan mempengaruhi besar kecilnya slack budgeting yang dilakukan. Manajer level bawah dengan tingkat penalaran moral yang rendah akan cenderung untuk mengutamakan kepentingan pribadi, mereka akan memilih tindakan yang hanya menguntungkan kepentingan pribadi tanpa mempertimbangkan norma-norma yang berlaku dan akibat atas tindakan yang diambil tersebut. Sehingga dalam tindakan penyusunan anggaran pun akan lebih cenderung untuk melakukan slack budgeting.

Hipotesis kelima menyatakan bahwa ketika skema kompensasi perusahaan adalah slack inducing, dan manajer memiliki self efficacy yang rendah, maka manajer yang memiliki penalaran moral yang rendah akan lebih cenderung untuk melakukan slack budgeting dibandingkan dengan yang memiliki penalaran moral yang tinggi. Hasil uji statistik menunjukkan nilai signifikansi sebesar 0.015 , hal ini berarti bahwa terdapat perbedaan sikap pada saat skema kompensasi yang ada pada perusahaan adalah slack inducing, dan manajer memiliki tingkat kepercayaan diri yang rendah, maka 
manajer level bawah dengan penalaran moral rendah cenderung melakukan tindakan slack budgeting dibandingkan dengan manajer level bawah yang memiliki tingkat penalaran moral yang tinggi. Pada manajer level bawah yang memiliki tingkat penalaran moral yang tinggi akan tetap mempertimbangkan keputusan etisnya. Walaupun berada pada situasi yang memungkinkan untuk mendapatkan keuntungan pribadi. Hal ini disebabkan karena pertimbangan etis yang dimiliki. Manajer level bawah yang memiliki penalaran moral yang tinggi tetap beranggapan bahwa melakukan tindakan slack budgeting tidak sesuai dengan norma yang berlaku dan akan dapat merugikan perusahaan.

\section{SIMPULAN}

Berdasarkan hasil analisis yang telah dilakukan sebelumnya, maka peneliti dapat menyimpulkan bahwa: (1) Skema kompensasi dapat berpengaruh terhadap tindakan slack budegting yang dilakukan oleh manajer level bawah. (2) Self efficacy tidak berpengaruh terhadap tindakan slack budgeting yang dilakukan oleh manajer level bawah. (3) Interaksi antara situasi skema kompensasi slack inducing dengan manajer yang memiliki self efficacy yang rendah tidak berpengaruh terhadap tindakan slack budgeting. (4) Tingkat Penalaran moral manajer level bawah berpengaruh terhadap tindakan slack budgeting. (5) Pada manajer level bawah yang memiliki tingkat penalaran moral yang rendah dan tingkat self efficacy yang rendah, interaksi dengan skema kompensasi slack inducing berpengaruh terhadap tindakan slack budgeting.

Penelitian ini juga memiliki beberapa keterbatasan, diantaranya yaitu: (1) Kasus dalam eksperimen ini disajikan dalam bentuk ilustrasi yang merupakan penyederhanaan dari situasi dan kondisi di dunia nyata. Sehingga kasus yang disajikan dalam instrumen eksperimen belum mencerminkan secara penuh kasus yang terjadi di lapangan. (2) Masih terdapat partisipan yang tidak memahami prosedur penelitian, sehingga masih terdapat partisipan yang tidak lolos uji manipulasi. (3) Generalisasi hasil penelitian yang masih terbatass yang disebabkan oleh partisipan penelitian yang terbatas hanya mahasiswa S1 Jurusan Akuntansi Fakultas Ekonomi UNP.

Berdasarkan kepada keterbatasan yang ada, maka untuk penelitian selanjutnya dapat dilakukan: (1) Perlakuan yang diberikan kepada partisipan mungkin dapat lebih dikembangkan sehingga partisipan dapat memahami seluruh prosedur penelitian. (2) Partisipan penelitian yang mungkin dapat lebih diperluas sehingga hasil penelitian dapat digeneralisasi. (3) Penelitian selanjutnya mungkin dapat menambah variabel lain yang relevan 


\section{DAFTAR PUSTAKA}

Abdullah, I. (2013). The Influence of Horizontal Equity, Self Efficacy, and Ethical Position on the Creation of Budgetary Slack. Disertasi. Virginia Commonwealth University.

Ajzen, I. (1991). The Theory of Planned Behavior. Organizational Behavior and Human Decision Processes, 179-211.

Anggraeni, A. (2016). Pengaruh Self Esteem, Etika, Skema Kompensasi Slack Inducing dan Truth Inducing serta Asimetri Informasi terhadap Budgetary Slack: Study Eksperimen pada Konteks penganggaran Partisipatif. Skripsi. Fakultas Ekonomi Universitas Negeri Yogyakarta.

Apriantini, N. K., Adiputra, M. P., \& Sujana, E. (2014). Pengaruh Partisipasi Anggaran terhadap Senjangan Anggaran dengan Penekanan Anggaran dan Komitmen Organisasi sebagai Variabel Moderating. JIMA Undiksha, Vol. 2, No. 1.

Ardiyani, F., \& Sukirno. (2017). Pengaruh Self Efficacy, Reward and Punishment, dan Asimetri Informasi terhadap Budgetary Slack: Studi Eksperimen pada Konteks Penganggaran Partisipatif. Jurnal Nominal, Vol. 6 No.1 : 66-80.

Bitlinandas, F., Kamaliah, \& Susilatri. (2018). Pengaruh Partisipasi Anggaran, Penekanan Anggaran, dan Asimetri Informasi terhadap Budgetary Slack dengan Ketidakpastian Lingkungan sebagai Variable Moderasi (Studi Empiris pada OPD Kabupaten Kampar Tahun 2018). Jurnal Online Mahasiswa, Vol. 1 No.1.

Chong, V. K., \& Loy, C. Y. (2015). The Effect of A Leader's Reputation on Budgetary Slack. Advances in Management Accounting, Vol. 25 : 49102.

Chong, V. K., \& Sudarso, D. (2017). The Effect of Organizational Ethical Climate and Peer Monitoring Control Systems on Budgetary Slack: An Experimental Study. Asia-Pacific Management Accounting Journal, Volume 11 Issue 2, 42.

Damayanti, G. A., \& Wirasedana, W. P. (2014). Pengaruh Partisipasi Anggaran, Reputasi, dan Etika pada Kesenjangan Anggaran pada SKPD di Pemerintahan Kota Denpasar. E-Jurnal Akuntansi Universitas Udayana, Vol. 9, No. $1: 133-142$.

Dunk, A. S. (1993). The Effect of Budget Emphasis and Information Assymetry on The Relation between Budgetary Participation and Slack. The Accounting Review, 400-410.

Dwisariasih, J. (2013). Pengaruh Asimetri Informasi, Budaya Organisasi, dan Kohesivitas Kelompok terhadap Hubungan Partisipasi Anggaran dan Kesenjangan Anggaran. Skripsi. Fakultas Ekonomi Universitas Negeri Padang. 
Efrilna, P. (2018). Pengaruh Skema Pemberian Insentif dan Tanggung Jawab Personal terhadap Budgetary Slack. Fakultas Ekonomi Universitas Negeri Padang.

Falikhatun. (2007). Interaksi Asimetri Informasi, Budaya Organisasi, dan Group Cohesiveness dalam Hubungan antara Partisipasi Penganggaran dan Budgetary Slack (Studi Kasus pada Rumah Sakit Umum Daerah se-Jawa Tengah. Simposium Nasional Akuntansi (SNA) $X$, Makassar (26-27 Juli 2007).

Hobson, J. L., Mellon, M. J., \& Stevens, D. E. (2011). Determinants of Moral Judgements Regarding Budgetary Slack: An Experimental Examination of Pay Scheme and Personal Values. Behavioral Research In Accounting, Vol. 23 No.1 : 87-107.

Innocenti, S., \& Cowan, R. (2019). Self-Efficacy Beliefs and Imitation: A Two-Armed Bandit Experiment. European Economic Review, 1-37.

Kohlberg, L. (1969). Stage and Sequence: The Cognitive-Development Approach Moral Action to Socialization. Chicago: Rand McNally.

Nugraheni, T. S., \& Sugiri, S. (2004). Pengaruh Reputasi, Etika, dan Self Esteem Subordinat terhadap Budgetary Slack di bawah Asimetri Informasi. Journal of Indonesian Economy and Business, Vol. 19 No. $4: 375-388$.

Prabandari, S. P., \& Sholihah, P. I. (2014). The Influence of Theory of Planned Behavior and Entrepreneurship Education Towards Entrepreneurial Intention. Journal of Economics, Business, and Accountancy Ventura, Vol. 17 No. $3: 385-392$.

Priyetno, A. (2018). Pengaruh Partisipasi Anggaran terhadap Budgetary Slack dengan Gaya Kepemimpinan dan Pertimbangan Etika sebagai Variabel Moderasi. Jurnal Akuntansi Fakultas Ekonomi Universitas Negeri Padang, Vol. 6, No. 1.

Puspita, L. M., \& Lubis, I. R. (2017). Pengaruh Reputasi Pemimpin terhadap Budgetary Slack dengan Kejujuran sebagai Variabel Intervening: Sebuah Eksperimen. Simposium Nasional Akuntansi (SNA) XX, Jember $1-14$.

Rest, J. R., Narvaez, D., Thoma, S. J., \& Bebeau, M. J. (2000). A NeoKohlbergian Approach To Morality Research. Journal of Moral Education, 381-395.

Rifqi, R. A., Subekti, I., \& Rahman, A. F. (2017). The Effect of Budgetary Participation to Budgetary Slack With External Pressure As Moderating Variable. Journal of Accounting and Business Education.

Sampouw, C. E. (2018). Experimental Study: The Influence of Pay Scheme and Personal Value to Budgetary Slack. Journal of Applied Management, Vol. 16 No. 4 : 614-621.

Savitri, E., \& Sawitri, E. (2014). Pengaruh Partisipasi Anggaran, Penekanan Anggaran, dan Informasi Asimetri terhadap Timbulnya Kesenjangan Anggaran. Jurnal Akuntansi, Vol. 2 No. 2. 
Scott, W. R. (2015). Financial Accounting Theory. 7th Edition. Canada: Pearson Canada.

Sprinkle, G. B. (2003). Perspectives on Experimental Research in Managerial Accounting. Accounting, Organizations, and Society, 287-318.

Stevens, D. E. (2002). The Effects of Reputation and Ethics on Budgetary Slack. Journal of Management Accounting Research, 153-171.

Sugiyono. (2017). Metode Penelitian Kombinasi. Bandung: Alfabeta.

Suharyadi, \& Purwanto. (2017). Statistika untuk Ekonomi dan Keuangan Modern. Jakarta: Salemba Empat.

Waller, W. S. (1988). Slack in Participative Budgeting: The Join Effect of A Truth-Inducing Pay Scheme and Risk Preferences. Accounting, Organizations, and Society, Vol. 13 No. 1 : 87-98.

Weitzman, M. L. (1976). The New Soviet Incentive model. The Bell Journal of Economics, 251-257.

Wirjono, E. R., \& Raharjono, A. B. (2007). Pengaruh Karakteristik Personalitas Manajer terhadap Hubungan antara Partisipasi dalam Penyusunan Anggaran dengan Kinerja Manajerial. Jurnal Kinerja, Vol. 11 No.1 : 50-63.

Young, S. M. (1985). Participative Budgeting: The Effects of Risk Aversion and Asymmetric Information On Budgetary Slack. Journal of Accounting Research, 829-842. 